\title{
History And Moral Education In Nation Building: A Discourse On The Nigeria's Broken Systems
}

\author{
Yusuf Maigida Abdulrahman \\ Department of Educational Foundations \\ University of Port Harcourt, Port Harcourt - Nigeria
}

\begin{abstract}
Systems are fast collapsing in Nigeria, including education. The good old days of the country were devoid of all the negativities of today. Studies have shown that a number of forces and causes were responsible for where the country has come to find herself. However, to be historical is sine-qua-non to retracing our bearing and recognizing education as a potent instrument for a morally upright society. The connection between history and moral education was chronicled, with clear focus on the place of history and moral education from the retrospective standpoints; capturing colonial and postcolonial characteristics. Ugly state of affairs in Nigeria and ways of addressing the situations were highlighted, for nation building. Character training and promotion of right type of values recommended.
\end{abstract}

Keywords: History; Moral Education; Nation-Building; Broken System.

\section{INTRODUCTION}

Outcries about Nigerian education do not exclude quality concern, inadequate facilities and equipment, moral decadence and all forms of indiscipline; having a toll on the society for decorum. It is a sing song now that our system of education has collapsed or broken. In fixing a broken system, it will be good to be retrospective and consistently flash back to examine where we have got it wrong along the line; after which the mind of everyone is expected to accept the need for decorum and do things right, for the much needed development to be realistic. Identifying and appraising history and moral education have been considered the right steps to be taken first. In this regard therefore, History is everything and in everything, there is history. Significantly, Ikime in Abdulrahman (2015) submits that:

\begin{abstract}
History is the memory of human group experience. If forgotten or ignored, we cease in that measure to be human. Without history, we have no knowledge of who we are or how we came to be, like victims of collective amnesia groping in the dark for our identity. It is the events recorded in history that have generated all the emotions, the values, the ideals, that make life meaningful, that have given men something to live for, struggle over, die for. (p. xii)
\end{abstract}

Knowing ones history is important. Failure to do this is a disaster and doing it correctly will give direction to our existence as people or community who will have legacies to be left behind for the succeeding generations. 
Generally in any society, rules and regulations are set as standard for the existential interaction among the people and their environment, consequently defining the characteristics of the society, for its perception as either good or bad. Any society left unguarded is doomed and the consequences are unimaginable. The decadence in any society does not just start over night, but accumulated and cultivated habits, mostly from childhood. For the society therefore, to be guarded and guided, it begins with a serious work on the psyche of children in their early or formative years of life, where the adult members of the society are to positively and morally influence their attitude. Plowden Report (1967) has it that:

\section{children and their primary schools declared that 'one obvious purpose of education is to fit children for the society in which they will grow up... for such a society they will need, above all, to be adaptable and capable of adjusting to their changing environment.}

Basically, it is a consensus now that one of the purposes of education is to enable children understand the society in which they live. If education therefore serves that purpose and history is about the society which we live in, then the role of history cannot be over-emphasized. If Jesus or Mohammed is considered a model to their religious adherents, these two men are no longer with us and everything about them is in retrospect. In referring or sermonizing about them, we are being historical. In a more direct way of explaining this, the Holy Bible and the Holy Qur'an were written over 2000 and 1500 years ago respectively, therefore, the contents that are believed and used as our moral guides are historical. Religious teachings nowadays are about characters and morality, all of which the scriptures had envisaged the problems that would plague the human societies and accordingly provided the guides for good conducts and godly undertakings. Without the Holy Books, the world would not have known peace or enjoy decorum from generation to generations. There are lessons from the Books of John, Zachariah, Corinthians, Galatia, Ephesians and in many of the Qur'anic verses as well, there are dos and don'ts; regulating the conducts of the believers. In both scriptures, there are available lessons to learn and the contents remain till tomorrow, historical.

In this case therefore, all that exists to regulate humans for a peaceful and godly society must have inherent lessons to be learnt from them. Experience, they say, is the best teacher. Whatever that is considered an experience must have happened (historical). This is to mean that history is the teacher of morality. If any error has been committed, history will be used to correct it and anything not yet happened, history must have envisaged it and the antidote already there from history, whenever they occur. History and morality are inseparable.

\section{Conceptual Clarification}

Following the above clarifying expressions about the connections between history and morality, a more specific clarification of the concepts is very necessary to prepare the minds of everyone for a more elucidating, critical or controversial discourse about the topic assigned.

\section{History, what is it?}

Generally, history has always been recognized and known by scholars and practitioners in the field, including this author himself at one time before now, as what concerns the past and examines the 'present' for the future. Defining history is a tripartite or triangular expression which involves using the words 'past, present and future' to convey the message of what history is all about. The 
author has henceforth considered that there is no place for the word 'present' in whatever that is historical, as his research efforts have left him with the understanding and conclusion that there is no 'present' in history, but 'the past' and 'the future'.

Historical issues or events, though, may be contemporary in outlook or manifestations; they are just current, but in the literal meaning of 'present', history is devoid of anything present. There is no controversy that what has happened is past and what will happen is the future, but people consider that what comes between the two is the present, which in actual fact does not exist. If everyone will agree that history is what is 'said' or 'done', then there is no 'present'. What people see as the present is even the past in itself, but the immediate past. Once the mouth is opened, for instance, to utter (say) a word, soon as the lips are closed, it is already in the past. So also, if a person is slapped, the slap has already been executed (done), it is immediately in the past. In furtherance of this discourse, it should be noteworthy that everything that happened in the life of everyone 'today' is past, despite that they all happened today. However, everyone can still hold to whatever in their perception is history.

In leveraging on the words of Rene Descartes, that is; 'cogito ergo sum'. "I think, therefore, I am". That I believe as an educational historian and maintain that there is no 'present' so it is and to me, it is. However, for the purpose of this paper, the researcher operationally adopts history definition as ...the reconstruction of the past. It may also be seen as an unending dialogue between the past and the future.

\section{Moral and Education}

Moral is the standard requirement and expected code of behaviour considered acceptable, not by an individual, but a group or society. In other words, moral and education are always meaningful, if they are treated together. Moral, as maintained above, is a requirement which is not automatic, but to be learnt and imbibed with sense of judgement; for societal living and acceptance.

Education is generally conceived as a process of imparting knowledge and a means of acquisition of skills by younger generations of a society. In the process, young members of the society are made to develop the potentials within them to the fullest. They are made to learn the values, norms, the act of working and living obtainable in the society, for future contributions of the individuals to the growth and development of their communities and towards a happy life within the society (Moses, 1981; Yoloye, 1993). Education is as old as man himself and is considered an essential factor in his life and struggles to conquer and subdue the features of his physical environment.

In general, moral education may be conceived as education in personal relationship. It is a process of getting the learner to develop responsible attitudes towards others, in fairness, under free and rational considerations and to develop also the skills of judgment after critical and logical reflections over what is considered to be right or wrong and the feelings of the others. Although, moral education is not synonymous with religious education, it constitutes in great part a factor in the moulding of human character. Moral training connotes the act of bringing up children so that they can conform to the good principles of behaviour (Harris, 1970:72).

Education has moral and there is moral in education. If education is to impart knowledge, affect attitude and influence the behaviours; it therefore means that what education seeks to ultimately 
achieve in the individuals is acceptable and responsible personality. Moral, Ethics, Values or code of conducts have become commonly used terms to describe the expected ways and manners in which everyone should operate. This is also corroborated by Ajuzie (2006) who recognizes that in every society, there must be yardsticks for deciding the right and the wrong courses of action. This is the situation in our homes, when the family set standards for members to guide their upbringing; the schools set rules and regulations for expected behaviours from the students and personnel; different establishments have their codes of conducts, upon which members and administrators should act or interact. Interestingly, the formal or informal society is also characterized with established norms that every individual is expected to internalize. All of these, in whatever ways they must have been enshrined or designed for human relations, are for the good conducts, because they are moral requirements of the establishments (institutions or organizations).

It is clear that morality is strongly connected with childhood lifestyles and the different orientations they are given. Children are at the centre of whatever the society would be known for or called, because they grow up with whatever they were exposed. Further recognition of a child in what any society becomes is evident in Asodike and Abdulrahman (2013) quoting from 'An Essay Concerning Human Understanding published in 1690 by the British philosopher - John Locke who states that the mind of the individual is a tabula rasa, or a blank slate, upon which experience imprints knowledge. This is the believe held by many psychologists which is interpreted to mean that what the child will grow up to offer the society must be made available early before the society itself bequeaths negative ideals into him. In a related manner, the stateuniversity.com (2019) also affirms that most thinkers, educational practitioners, and parents even acknowledge that children are born helpless and need the care and guidance of adults into their teens and often beyond. More specifically, children need to learn how to live harmoniously in the society. Some of us even believe that it is not when the child comes to the world that he/she begins to learn about his environment. From the womb according to Gabriel (2018), psychologists have proven that neonates, even foetus in the uterus respond to stimuli - sound, heat, cold and other environmental forces. For this, it indicates that the child, even before birth was already part of the society, feeling the society; but the duty of the society to model the child in conformity with the standards which the society operates.

From the foregoing, it is crystal clear that the degeneration in every society, including Nigeria has always been an ugly thing rearing its head, but not nib in the bud. The root or the genesis of societal degeneration is the unguarded behaviours manifested early in life by the child and which he grows up with and consequently constituting nuisance to the society. To nib this in the bud simply means that all that the society is negatively characterized would have been taken care of by the teaching of societal norms for moral uprightness. Today, there are cases of ritual killings, insurgency, militancy, robbery, kidnaps and other unwholesome practices like theft, prostitution, teenage pregnancies etc. which are begging for solutions.

In view of the above, teaching morality is what is considered the duty of many agencies, such as the family - where moral education of children is an inalienable responsibility of parents. A typical traditional Nigerian family lived the above principle to the letter. Shame used to be the portion of the family of a moral misfit, hence the serious effort to get their children behave well within and outside the family; the school - where knowledge, attitude and practices are a combined package 
for learners' positive and responsible living; the religious bodies through preaching and homily, behaviours are bound to be positively influenced, etc.

Everything about Nigeria and education is history. Moral education in Nigeria is historical in whatever way you may want to look at it. If education has history, then moral education which is a part of educational tradition is history.

\section{Moral Education and its Agents}

It is good to mention here that the school is a major training ground for morals. However, there is no doubt in the submission of Wootton in Kay (1975) that contemporary literature on moral education tends to present home and school as the principal agents of moral education. To be more precise of the contemporary society, the school does more than the family/homes in moral or ethical development. The whole essence of schooling is to positively influence the behaviours of the learners, consequently enable them leave school with such attitude the society will accept. That family is second to the school in the moral upbringing of the children indicates that, the writer does not in a total agreement with the assertion that it is on the parents lies the responsibility of educating the children morally'.

Children stay in school for upward of 6-7 hours a day, 4 to 5 hours for home presence in the day's 12 hours before going to bed. Note that home-works/assignments are usually part of the 4-5 hours of presence in the homes. They sleep 8 to 9 hours and when they are woken up around 4 or 5am; they are again set for school by 6 or $7 \mathrm{am}$. The time spent in school for the attainment of physical, mental, social and psychological development is more than the one stayed in the family. In addition to this, some even stay in the boarding house for schooling, from primary to tertiary levels, where they learn to do most, if not all things, in accordance with rules and regulations of the schools. A regimented life of obedience in school is a life of honesty, hardwork, resilience, peaceful coexistence, Godliness, good sense of judgement between the good and the bad. These qualities happen spontaneously in the individuals, since there would be no other ways of life than compulsory adjustment to the rules. Atimes, the name of a school-head or a teacher, even a senior in the day/boarding school may be the beginning of wisdom to the learners.

It is good to mention too, whatever the expected code of behaviour in any institutions or organizations; the school must have equipped the individuals with the character for livelihood. The school teaches the individual how to internalize the societal norms and values. For instance, medical training goes with the teaching of the professional ethics of the field, so also in the legal profession, in journalism, in the military, nursing, engineering practice, even in the teaching profession itself; the practitioners or personnel are regulated by their learnt professional ethics.

i. Education for morals. The various expressions about what moral is can be tied to education. Education in the words of R. S. Peters, 'it is no longer necessary defining education because of it network of contradictions and complexities which criss-cross and overlap'. However, Peters maintains that education should be what is worthwhile.

ii. Importantly, the argument of Danziger (1973) that the main purpose of education was to teach pupils about the society in which they would live. He further postulates that the way to do this was to teach them about the evolution of the society.

iii. In both our National Anthem and National Pledge, they are moral guideposts. 
Abdulrahman, Y. M. (2020) History and Moral Education In Nation Building: A Discourse On The Nigeria's Broken Systems. Archives of Business Research, 8(4). 79-94.

\section{TRADITIONAL/INDIGENOUS EDUCATION'S PERSPECTIVE}

Education that is indigenous to the people or community where it is given, for successive generation to experience is traditional education. This system of education is basically for functionalism and by extension, political participation and social responsibility (Fafunwa, 1974, Osokoya, 1989, Kosemani \& Okorosaye-Orubite, 2002). Functionalism is the hallmark of traditional education. This is associated with indigenous education and it expects every individual member of the society to play his or her role in such a way that conforms to the societal requirements. A functional man or husband is he who is a responsible man, catering and providing for the needs of his family. Any man who cannot fulfill this requirement is not a functional member of the society, therefore, possess no moral. A farmer is functional if he is able to plant and have a bumper harvest for his family and others for sale to the community. A fisherman is also functional if his nets can trap abundant fishes for his immediate family and the markets. It is also the case for others in traditional occupations.

To be functional also requires that a father/husband should prove he is a father/husband, a mother/wife as a mother/wife and children as worthy children. For each or everyone to be functional, it means the standard set by the society must be met, therefore a moral obligation.

Although, values are universal - honesty, loyalty, faithfulness, goodness, love, kindness etc. are part of every society. The morals in these values are culture-bound e.g what a society considers as right may be wrong in another society. In some societies, handshake or standing to greet an elder is immoral and condemned, but morally welcomed in some others. However, in whatever position or how it is carried out, the definitive is showing 'respect'. To make soap in the Igboland, they burn wood and use the ashes to make soap. Among the Yoruba, they burn plantain leaves to make same, but the universal thing is the addition of potash and palm oil to give same result. The question of moral bothers on the societal norms, traditions, customs and values.

\section{History of Education and the Missionaries}

Provision of education by the individuals, organizations or government remains a moral obligation for the transformation and progress of the societies and the people. There is therefore no contention in the reality that if not for the Christian Missionaries, Nigerians would not have been formally educated'. History has it that all over the world, provision of education was first by the private individuals or groups. In the case of Nigeria, formal education began with the Missionaries, to bring up people in the ways of the Lord and be useful to the society through the teaching of religion and morals. Historically, the mission of schools has been to develop in the young, both the intellectual and the moral virtues. Concern for the moral virtues, such as honesty, hard-work, responsibility, kindness and respect for others, is the domain of moral education which the Missionaries strongly pursued.

European Missionaries actually came for evangelism, but felt it was morally justified to give education which will assist them achieve proper spread of gospel. Importantly, the Act of 1833 passed by the British Parliament for abolition of slave trades was responsible for the repatriation of Africans in diasporas to a long acquired town in 1787 in Sierra Leone for the returnees (freed slaves) to settle. This town was eventually called 'Freetown'. Also, the revival of missionaries' activities in London, leading to the proliferation of a number of Missionary Societies such as Baptist Missionary Society (1792), London Missionary Society (1795), and Church Missionary Society 
(1799). The revival zeal of these Missionary Societies prompted their massive movement into the field to win souls and give education, with the Bible in one hand and slate in the other. These facilitated the Christian missionaries' establishment of schools such that included: Wesleyan Methodist, with Thomas Birch Freeman and a couple - Mr and Mrs Williams de Graft arriving at Badagry, precisely on the 24th September 1842; establishing the very first private primary school in 1843 and named 'Nursery of Infant Church.

Still in 1842, but on the 19th December; the Church Missionary's Society (CMS, now the Anglican) arrived Abeokuta for evangelical survey, hoping to return later for real evangelism in 1844, but they were disappointed to meet the community in mourning mood of their late monarch - King Sodeke of Egba (Abeokuta). Eventually, Henry Townsend and two gentlemen in person of Rev. (later Bishop) Samuel Ajayi Crowther and Rev. C. A. Gollmer accompanied Townsend to Abeokuta to start evangelism in 1846 and the immediate establishment of two schools, one for boys and the other for girls. The third adventure took the missionaries of the Presbyterian Church of Scotland led by Rev. Hope Masterton Waddel to Calabar in 1846. It was in 1850 that the Southern Baptist Convention under the leadership of Rev Thomas J. Bowen arrived in Nigeria, but started the first school in 1853 at Ijaiye and another at Ogbomosho in 1855. The year 1857 heralded the CMS Niger Mission with Rev. Samuel Ajayi Crowther and Rev. J. C. Taylor as front-liners. With the cooperation of Niger explorer - Mc-Gregor Laird, schools were founded at Gbebe and Onitsha. The school at Idda in now Kogi State was established in 1864, and other ones successively established at Bonny and Akassa. Roman Catholic arrival into the country in 1868 with Padre Anthonio settling down in Lagos was a booster to evangelism and educational engagement. Much later in 1887 was the Qua Iboe Mission registering their impact at Eket and Ikot Ekpene. So also were many missions in pioneering modern education in Nigeria.

The roles of the Christian Missionaries remain invaluable in the history of Nigerian education and the promotion of morals among school children. Moral was pursued and instilled in the children, for them to grow up with good and acceptable conducts in the society. The waywardness of school children today was not there under the missionaries' exclusive control of education.

\section{History of Education and the Nigerian Colonial Administration}

The colonial Government also got involved in the provision of education after about 40 years of Missionaries exclusive control. The first intervention of the colonial government was the grant-inaid of $£ 30$ Pounds to the three missionary bodies in 1872 with no condition, to assist in their educational works and increased to $£ 200$ Pounds in 1877 with conditions on a number of requirements to be met. There was moral in doling out the grants. First, colonial government sat on the fence for 40 years without educating their subjects and the missionaries were churning out pupils who passed out of missionaries' schools and work in the colonial civil service. The moral reason was in the appreciation of the good work of the missionaries for building quality human resources.

When rivalry started among the missionaries and the quality of education began to drop, the colonial government also had a moral reason for the introduction of regulatory policies in the name of Education Ordinance to check the trend. From 1882 till independence, colonial government never ceased to promulgating series of ordinances in 1887, 1916, 1926 and so on; to address the development in education. When it was also necessary, they started establishing schools. The first 
Government primary school in Nigeria was established for the Muslims in Lagos in 1899, having a moral justification to do this, following the protest in 1895 over the conditional acceptance of Muslim children in the mission schools. The need to have Government secondary school as a model and correction for the missionaries, resulted in the establishment of King's College in 1909 and later the thought that women/girls should be educated, following the report of the Phelps Stokes Commission, the Queen's College was established in 1927.

Higher education also began with the establishment of Yaba Higher College in 1932, following the appointment of E.R.J. Hussey as the first Director of Education in Nigeria. University education was also granted the country for the first time in 1948, as a University College of London. In colonial days there was rivalry/competition among the three regions for development. Universal Primary education was the first aspect of response to the colonial constitutional provision in 1951 where each region raced one another. Not too long that Nigeria was hopeful of self rule, to attain political independence. At the eve of this independence, Ashby Commission was set up. The findings and the recommendations of the Commission spurred the establishment of more universities in the country.

\section{Post-Independence Nigerian Education}

From the foregoing, the first post-colonial university was the University of Nigeria at Nsukka, established 7 days after independence in 1960. The universities of Lagos, Ife and Ahmadu Bello University were all established as post-independence universities in 1962, including an upgrade and renaming of University College Ibadan to a full-fledged and autonomous University of Ibadan; justifying the need for higher education across the regions.

Further justification for the establishment of more universities came with the federalization of tertiary education and produced 7 additional Universities under the $3^{\text {rd }}$ National Development Plan of 1975 to 1980 , thus: 
Table 1: Seven (7) Universities in 1975, From the Third National Development Plan, 1975-80

\begin{tabular}{|c|c|c|c|c|c|}
\hline $\mathbf{S} / \mathbf{N}$ & Institution & Year & Status & Administrator & Designation \\
\hline 1. & $\begin{array}{c}\text { University College, Port } \\
\text { Harcourt }\end{array}$ & 1975 & $\begin{array}{l}\text { University College } \\
\text { of University of } \\
\text { Lagos }\end{array}$ & $\begin{array}{l}\text { Prof. Donald E. U } \\
\text { Ekong }\end{array}$ & Principal \\
\hline 2. & $\begin{array}{l}\text { University College, } \\
\text { Ilorin }\end{array}$ & 1975 & $\begin{array}{l}\text { University College } \\
\text { of University of } \\
\text { Ibadan }\end{array}$ & $\begin{array}{l}\text { Prof. Oladipo. } 0 . \\
\text { Akinkugbe }\end{array}$ & Principal \\
\hline 3. & $\begin{array}{c}\text { University College, } \\
\text { Kano }\end{array}$ & 1975 & $\begin{array}{l}\text { University College } \\
\text { of Ahmadu Bello } \\
\text { University, Zaria }\end{array}$ & Dr. Mahmud Tukur & Principal \\
\hline 4. & University of Calabar & 1975 & Autonomous & Prof. E. A. Ayandele & $\begin{array}{c}\text { Vice } \\
\text { Chancellor }\end{array}$ \\
\hline 5. & University of Jos & 1975 & Autonomous & Prof. E. O. Onuaguluchi & $\begin{array}{c}\text { Vice } \\
\text { Chancellor }\end{array}$ \\
\hline 6. & University of Maiduguri & 1975 & Autonomous & $\begin{array}{l}\text { Prof. E. U. Essien- } \\
\text { Udom }\end{array}$ & $\begin{array}{c}\text { Vice } \\
\text { Chancellor }\end{array}$ \\
\hline 7. & University of Sokoto & 1975 & Autonomous & Prof. S. A. S. Galandaci & $\begin{array}{c}\text { Vice } \\
\text { Chancellor }\end{array}$ \\
\hline
\end{tabular}

Source: Abdulrahman-Yusuf, M. (2014) Nigerian Educational History and Policy.

There is sense in this historical chronicle and justification, because every region has at least a university. In the consideration to be modest and liberal, State governments were also granted by the federal, the rights to establish universities, following the provision of 1979 Constitution, transferring tertiary education into the Concurrent List and Rivers State taking the lead by establishing Rivers State University for Science and Technology (RSUST). At every point in time, justification was manifested for every State to have sense of belonging, by a way of federal presence in terms of tertiary institutions. Universities of Technology and Agriculture were established by the Federal Government in states where there were no conventional federal universities, for example in Owerri and Umudike respectively.

Federal government also established at least two Unity Schools in every state of the federation, i.e. Federal Government Colleges - one mixed and one girls or boys only, including in some states, those which are for Science and Technical. Also, establishment of tertiary institutions in the policy commitment of government for certification is first to see that the requirement of being found worthy in character and in learning be made sacrosanct. This is also an indication that government realises that she holds moral duties to develop the capacity of her subjects for socio-economic, political, religious growths.

\section{Characteristics and State of Affairs in Nigeria}

Unlike the distant past experiences of Nigeria which had some level of decorum and serenity in the different aspects of our national lives - be it in political, economic, religious, environmental/geographical, communal/family, educational and other interacting institutions between man and the society; things were better than the current manifestations. Things were probably better because of change in orientations. First, the traditional institutions in the then society were appropriate and effective for the growth of the society. Traditional society had a 
Abdulrahman, Y. M. (2020) History and Moral Education In Nation Building: A Discourse On The Nigeria's Broken Systems. Archives of Business Research, 8(4). 79-94.

regulated and respected traditions which even taboos played important roles. Modernisation/civilization came and the situations were still manageable, along the line, the system collapsed like the proverbial 'things fall apart' by respected literary giant, Chinua Achebe.

Today, the Nigerian society, though not cursed, unfortunate with a lots that have come to characterize and bedevil her existence. Take for instance, pervasive in our societies are issues or events bothering on moral questions, thus, we are plagued with:

$\begin{aligned} \text { i. } & \text { Corruption } \\ \text { ii. } & \text { Militancy } \\ \text { iii. } & \text { Insurgency } \\ \text { iv. } & \text { Armed robbery } \\ \text { v. } & \text { Kidnapping } \\ \text { vi. } & \text { Ritual killings } \\ \text { vii. } & \text { Political Killing } \\ \text { viii. } & \text { Domestic Violence } \\ \text { ix. } & \text { Poverty } \\ \text { x. } & \text { Collapsed buildings } \\ \text { xi. } & \text { Cheating }\end{aligned}$

xii. Stealing

xiii. Election Violence

xiv. Malpractices

xv. Bribery and Kickbacks

xvi. Communal Clashes

xvii. Bullying, Thuggery, Hooliganism and Cultism

xviii. Prostitution and Human Trafficking \& Teenage Pregnancy

xix. Forgery and all forms of racketeering.

In more specific ways, there are different levels of degeneration in the society, cutting across almost all sectors of our national lives, thus:

\section{Corruption}

Among the political office holders, corruption has been so endemic that a slogan of 'if we don't kill corruption, corruption will kill us' is a singsong. In our institutions and work places, corruption has become the norm. The consequences are not good stories to tell. Through corruption, we have come to the experience of no good roads, the health facilities are in a sorry state, schools are starved of quality personnel and materials. Poverty and penury are staring people in the face.

\section{Bribery and Kickbacks}

Mediocrity is the manifestation when money or undue gifts exchange hands. Bribery and kickbacks are the reason why merit is thrown overboard. People bribe their ways have imposed on the society the dangers of existence. Incompetency is generally the case and supposed professionals are found wanting. For example, medical practice where a surgeon has turned a butcher, building engineer with incessant record of failed project or collapsed buildings.

\section{Militancy, Kidnapping and Insurgency}

These are unpatriotic activities against the state and humanity. Taking arms against ones country is unhealthy and retrogressive, but this is what we unfortunate to see in our society. Insurgency is terrorism and no other name it should be called, particularly in the north of Nigeria. Lives are taken senselessly and mercilessly for an undefined cause, families losing their innocent breadwinners and loved ones. Kidnapping, as the name implies used to be limited to kids in those days, but it has graduated to the level that the act is perpetrated without human face. Huge amount is demanded for ransom, agonizing the captive and the relations. Sad enough, some even die in the hands of their captors who still ensure the ransom is hopelessly paid. 


\section{Ethnic/Communal Clashes}

The neighbourliness we used to enjoy has almost eroded in our societies. Slightest provocations or disputes have always degenerated into much escalated crisis that rage on for long, with bloodshed. We had had Ife-Modake crisis, Aguleri-Umuleri discord, Offa-Erinle massacre; recently EbonyiCross Rivers (Izzi and Yala), Ngbo-Agila crisis between Ebonyi and Benue States and many others. These have resulted in unending suspicions between and among communities, renewing their hostilities occasionally.

\section{Robbery and Stealing}

Highways are no longer safe, even residential apartments, with all theft or burglary alerts and barricades; houses are still not immuned to robbery. Nowadays, people cannot sleep with their two eyes closed. In those days when tradition was respected, there was no lousiness or laziness, everyone was gainfully employed; either as farmer, fisherfolk, hunter, carvers, palm wine tapper, blacksmith, traders etc. Similarly, stealing belong to the clan of robbery. This is also perpetrated in schools, corporate establishment, even in government offices. Properties/assets of organizations are in many individuals' houses, from office pin to generators etc.

\section{Violence and Killings}

Violence produces nothing other than losses and regrets. Whether domestic violence between couples, or any other form of violence, including political violence; most of these have resulted in deaths or deformity. Ritual killings have also taken centre stage in the country. People, old and young, man and woman continue to get missing and lifeless bodies are thereafter found around. Most current of these killings is farmer-herdsmen attack.

\section{Bullying, Thuggery, Hooliganism and Cultism}

Bullying is one of the known deviant behaviours among school children. It is believed that bullying graduates to something uncontrollable as the child grows, such as cultism. Today, thuggery, hooliganism and cultism are the characteristics of youth in and out of schools.

\section{Forgery and Cheating}

The culture of harwork is fast vanishing among the citizens. Cutting corners has now been decorated a societal cosmetics. Certificates are now being forged, legal declarations are no more reliable, as many have altered and doctored the original form of their document, even claim what they don't have. Cheating is part and parcel of the day to day business dealings or in business partnerships. Over-Invoicing and inflated prices of purchases on behalf of schools, governments and corporate organizations, as well as cheating amongst students, especially in examinations.

\section{Prostitution, Human Trafficking and Teenage Pregnancy}

Schools, particularly tertiary institutions are now training grounds for prostitution. Clubbing and parties have become fashionable among girls and ladies; they dress almost nude and line up or stand strategically on roadsides or designated spots awaiting their probable customers. At international level, human merchants, mostly women, addressed as Madam deceitfully lure these ladies into commercial sex works abroad. On the issue of teenage pregnancy, education suffers today because of this situation. Many promising young girls (mostly affected) are out of school and never courageous to go back, even after delivery and weaning the baby. 
Abdulrahman, Y. M. (2020) History and Moral Education In Nation Building: A Discourse On The Nigeria's Broken Systems. Archives of Business Research, 8(4). 79-94.

\section{Ethnic Militias}

There are a large number of ethnic militias across the country, agitating for one thing or the others, even those that could be peacefully resolved. In the list are:Oodua People's Congress (OPC); Indigenous People of Biafra (IPOB); Niger Delta Volunteer Force (NDVF); Movement for the Emancipation of the Niger Delta (MEND); Niger Delta Avengers (NDA); the militias according to Okorosaye-orubite (2017) are complemented by master associations vocalling the grievance and the real or perceived marginalisations of their respective ethnic nationalities - Ohaneze Ndigbo, Ijaw National Congress, Ijaw Youth Congress (IYC), Afenifere, Arewa Consultative Forum (ACF), etc. The question therefore, on the harmonious and united existence is yet to be answered.

The situations above are a true reflection of what our society is characterized, but never manifested in this magnitude before now, even if we had had near situations like these. All these are heartbreaking, they are maladies which the cure or antidote is moral education and going back to the drawing board (to be historical), reflecting on how we got things right before, then use such as case studies or insights to correct the situations now.

\section{Addressing the State of Affairs in the Nigerian Society}

The only way to surmounting these moral deficits is to go back to our history, that is, our past; reconstruct this past and in reconstructing the past (history), which is an unending dialogue between the past and the future; what we were doing right and how we were doing it that the individuals and the society were better for it, should be revisited. With the state (government) control of education nowadays, it is expected that better results than those of the missionaries period would be achieved. Contrarily, from a number of scholarly submissions, those admirable characteristics that used to be attributes of the educated e.g. gentleness, benevolence, loyalty, courtesy, tact, sense of duty, honesty, uprightness etc, are disappearing from the scenes. They are rather giving way, as indicated above, to brutality, bestiality and wildness of character, theft, strife, cultism and ritual killings even within the educational institutions, all forms of indiscipline and, poor academic performance. Human sacrifice has now returned to the Nigerian society in its fullest force, all happening in the absence of or in disregard for proper moral and religious instruction of the youth. Social evolution, decline in family roles, emergence of materialism and money mindedness have also been diagnosed as causal factors responsible for this decadence in morality (Iwe; Iheoma, in Otonti, 1983; Ugorji, 1992).

It has been variously submitted that any attempt to remedy the multiple socio-economic problems confronting Nigeria now should first begin with proffering remedies to the unsatisfactory state of public morality in Nigeria. To deal with all the identified moral problems therefore, education as earlier insinuated remains a potent vehicle that can reform and transform the society. Also, it is only with the children that the reform or transformation of the society can begin. Childhood is the most vulnerable period which impacts the overall development of an individual's personality (Pujarat, 2018). This should be taken seriously by the family, the school and the communities to pay more attention to moral requirements that children should be exposed.

Quite commendable that in schools now, particularly the private ones, no excuses are allowed for dissident, wayward, deviant or criminal behaviours. The school's rules and regulations cannot be flouted and the offender is pardoned. Family can overlook excesses of any member of the family, probably allowing room for second, even third or fourth chances, but the school's rules are 
sacrosanct. In the school setting, everyone, the administrators, teachers and students are very acquainted with the penalties or punishments for various offences, not limited to expulsion, rustication, demotion, sack and other labourious expiation and recompense for offences that are mild, but painfully felt punitive. Morality is highly enforced in schools. This is the reason why in my opinion the school should fully assume that role of 'in loco parentis' that is, the school becoming and discharging duties of parents to children while in school.

In addressing the situations, a number of measures are already taken, not that the state has turned a blind eye, but require to do more by showing serious commitment, thus:

i. The Nigerian government has recognized the ugly trends and realized that education can be used to solve these onerous problems. Government, through the Nigerian Educational Research and Development Council (NERDC) has designed a new national curriculum, now in use; where National Values is taught with religion at Basic level and Civic Education as a Core Cross Cutting subject at the Senior Secondary School Certificate Examination. With these, it is believed that morality issues bothering on nationalism, harmonious and peaceful co-existence, honesty, love, kindness and neighbourliness, perseverance, hardwork, contentment and so on would be taught to children, as it is believed that immoralities are best clipped or nibbed in the bud at that age.

ii. Review of Nigerian education policy, the National Policy on Education (NPE), consistently revised since the first edition in 1977, later in 1981 to ensure that the provisions of the 1979 Constitution are not antagonistic to the policy. In 1998 and 2004, the policy was revised to accommodate the needs of the times. Revised in 2008, but not published, but having the most current which is 2014 edition.

iii. To promote tolerance and religious understanding, the introduction into the Basic Education curriculum of a subject tagged Religion and National Values (RNV) is a clear indication that government is conscious of our country's diversity, even in religion, thereby marrying religion and values together for national development.

iv. Re-introduction of History as a Basic education subject. This also shows that history is recognized by government as a veritable instrument for the growth of a country. We can learnt a lot from our history, so that the error of the past would be averted

\section{Nation Building}

For nation building, morality is the answer which history provides. Going the memory lane is to be retrospective about how we have come to where we are. It must be clearer now that there are a number of inadequacies in the various systems in the country. The manifestations in the various sectors are not pointing to what we can be proud of. In the educational sector, political system or governance, infrastructural angle, religious dealings, health and safety aspects of life, etc. To be historical, everyone will agree that it was not as bad as we are seeing things unfolding today. This may hypothetically mean a moral deficit. If we can reflect on how the whole thing gradually became unencouraging, it will be done on us that there were things we failed to do. Teaching morals in schools by recalling the history of the experiences and the characters of the past, lessons (morals) would be learnt from our past, in the current undertakings and bracing up for the future of the society to become better. 
Abdulrahman, Y. M. (2020) History and Moral Education In Nation Building: A Discourse On The Nigeria's Broken Systems. Archives of Business Research, 8(4). 79-94.

Moral education, as earlier rendered is something that equips the learners with the qualities of hardwork, self-restraint or discipline, honesty, resilience, Godliness, contentment, peaceful coexistence, religious tolerance, patriotism etc.

In specific terms, the school is seen to be avenue for moral rectitude. Odimegwu (2016) submits that if the school cannot teach us first the values before teaching us Mathematics and English Language in the context of molding us, then the society is served menace to preserve. I therefore consider that giving a domesticated explanation to Pujara (2018) who also recognized the schools as the training ground for morality. To building a nation, the schools are the engineers, therefore:

i. For any society (or school) to exist, its members (students, teachers, and administrators) must share a number of moral virtues: they must be honest, responsible, and respectful of one another's well-being.

ii. If we are to live together peacefully in a pluralistic society, we must also nurture those civic virtues and values that are part of our constitutional tradition: we must acknowledge responsibility for protecting one another's rights; we must debate our differences in a civil manner; we must keep informed. A major purpose of schooling is to nurture good citizenship.

iii. On the distinction between moral and civic issues, including the nature of morality itself, students must learn about the alternatives, and teachers and schools should not take official positions on where the truth lies. The purpose of a liberal education should be to nurture an informed and reflective understanding of the conflicts.

iv. As children grow older and more mature they should gradually be initiated into a liberal education in which they are taught to think in informed and reflective ways about important, but controversial, moral issues. By this, they will have sense of judgement to determine for themselves the good or the bad.

v. Children are the foundation of our society the torchbearers of our nation. As a teacher and an influencer, one must take care of the moral training and basic qualities that are conferred on the children.

vi. School children should always be taught that it might be difficult, to tell the truth, but it is always essential to tell the truth. Stories and examples must be shared with them so that they have more clarity of thought. Give them time and treat them with patience at all times.

vii. It is also important to educate children to be disciplined and not to cheat while in class and in examinations. It is the duty of the school to orientate students that there are no shortcuts in life and life is an examination where there is no syllabus, the only thing that can get them though is a good character and speaking the truth at all times.

viii. It is important to educate children about the phenomenal activists and legends who exemplifies strength and has shown character to fight against all odds and championed the right causes to bring revolutionary changes. In Nigeria for example, nationalists like Dr. Nnamdi Azikiwe, Chief Obafemi Awolowo, Sir. Ahmadu Bello, Anthony Enahoro and others were selfless and patriotic leaders who desired good life for their people.

ix. Mention should be made of a number of past leaders who had opportunities, but never utilized that to enrich themselves. Some even died with a house or mansion of their own. People like Gani Fawehinmi who stood for justice throughout his life. A number of times, we have had in our society those who found money and valuable items, but never considered it blessings to them, but surrendered them to the police or media houses for announcements and subsequent return to the owner. 
$\mathrm{x}$. It should be of importance to tell children the severity of the punishment one might get committing crimes and serious offenses. They must be clear on what is right and wrong. Be a mentor than a parent and talk to your child as a friend, it would be a smoother process for them to learn. Share your past mistakes, its consequences and what you learned from it. Do not discourage their adventurous spirit but teach them to balance it between an adventure and a misadventure.

To do the above, the children will leave school and enter the society with best orientations that will positively impact on the society.

\section{CONCLUSION}

In the submission of Reggie-Fubara (1990), history acts as store-house for society's developmental records. There is no other way to interpret this submission of Reggie-Fubara than the renforcement of the fact that everything that will address the issue of morality is already contained in the history. History and moral education are inseparable.

a. In Nigeria, moral education is an integral part of the traditional education. Traditional lifestyle is entirely about functionalism requiring individuals to play their traditional roles as worthy member of the society. The Christian missionaries played important roles in pioneering modern education in Nigeria and the religious orientations full of godliness and moral also saw the people to a large extent becoming responsible

b. Moral education can be taught and will be vey effective, showing leadership by example. When the parents, adult members of the society, teachers, civic, religious and community leaders and everyone do what is right amidst the children, they always like to see elders or teachers doing what they can follow or emulate.

\section{RECOMMENDATIONS}

Since this paper has rated the school above all other agencies for moral development of the child, the school should therefore be more committed to character training. As it is known that the child is engaged with school activities for greater part of the day, the schools are therefore expected to allow the teaching of moral values be highly integral to their lessons in such a way that the child will imbibe the right type of moral values the society needs to move forward.

To achieve the above, teacher training and retraining will go a long way to equip the teachers the much needed skills and knowledge of teaching values and its re-orientation in the school. If the teachers lack these knowledge and skills, it then means they will have nothing to offer, but rather worsen the situations.

Many writers have perceived an urgent need for a diversification of the programme on moral and religious education. Making religion and moral education compulsory at all level is advocated, even at the university level, to be taught in General Studies. Though Civic Education is now a compulsory subject at the senior secondary level, but religion contains a lot more of morals that will bring out in the citizenry, a patriotic personality. Religion has been the principal anchor of morality in the history of mankind. Religion is the supplier of ideals that guide the construction of laws of human conduct (Okere, in Otonti \& Iheoma; 1983). Hence there is an inseparable bond between religion and morality. 
Adhering and obeying policy provisions on education is candidly advised. Let us drop the nomenclature Basic 1-9. No such things exists anywhere, we have moral obligations to play by the rules and not inventing what will spread like wild fire and cause confusion in the land. Primary school is still primary, from 1-6 and Junior Secondary, from 1-3.

\section{References}

Abdulrahman, Y. M. (2014). Nigerian educational history and policy. The beginning of the past and past of the future. Port Harcourt: M \& J Grand Orbit Communications

Ajuzie, M. V. (2006). Teaching of moral education in Nigerian schools. In P. N. Ndukwu \& O. O. Nwaubani (Eds). Reading in General Studies Education. Humanity and Social Science. Vol. 1. Lagos: St. Augustine's College of Education.

Asodike, J. D. and Abdulrahman, Y. M. (2013). Administration of early childhood care development and education (ECCDE) for national development: Relevance and delivery system in Nigeria. In J. D. Asodike, J. M. Ebong, S. O. Oluwuo and N. Abraham (Eds). Contemporary Issues in School Administration. Owerri: Alphabet Nigeria Publishers. Pgs 345-363 Accessible at: https://www.academia.edu/uniport/yusufabdulrahman

Danzinger, E. (1973). History in secondary school curriculum. Some considerations for drawing up a syllabus. M.Ed Thesis. University of Durham, Unpublished.

Gabriel, A. O. I. (2018). Education for sustainable national cohesion. 2nd International Conference on Education, Security for Sustainable National Cohesion. School of General Education. Alvan Ikoku Federal College of Education, Owerri.

Harris, A. (1970). Thinking about education. London: Heinemann Educational Books.

Odimegwu, O. (2016). Nigerian schools and moral education. Nigerian Tribune. https://www.tribuneonlineng.com

StateUniversity.com (2019). Moral education - A brief history of moral education, the return of character education, current approaches to moral education. Education Encyclopedia. education.stateuniversity.com

Okorosaye-Orubite, A. K. (2017). Grant this our new request. Inaugural Lecture Series, No. 137. Port Harcourt: University of Port Harcourt Press.

Otonti, A. N. \& Iheoma, O. A. (1983) (eds) New Perspectives in Moral Education. Ibadan: Evans Brothers (Nig) Ltd. ISBN 978-167-227-7 ...

Pujara, H. (2018). What's the meaning and definition of moral education? www.quora.com/whats-the-meaning-anddefinition-of-moral-education/answer

Reggie-Fubara, V. (1990). Trends in history methods for teachers. Port Harcourt: Pam Unique Publishing Company

Yoloye, T. W. (1993). Congruencies and variances in the Athenian and Nigerian selection of pupil for gifted education programme. Journal of Issues in Special Education, 1(2), pp. 56-59. 